\title{
Tiefer See - a key site for lake sediment research in NE Germany
}

\author{
Achim Brauer ${ }^{1,2}$, Markus J. Schwab ${ }^{1}$, Brian Brademann ${ }^{1}$, Sylvia Pinkerneil ${ }^{1}$, and Martin Theuerkauf ${ }^{3}$ \\ ${ }^{1}$ Section "Climate Dynamics and Landscape Evolution", GFZ German Research Centre for Geosciences, \\ Potsdam, 14473, Germany \\ ${ }^{2}$ Institute of Geosciences, Potsdam University, Potsdam, 14476, Germany \\ ${ }^{3}$ Institute of Botany and Landscape Ecology, University of Greifswald, Greifswald, 17487, Germany
}

Correspondence: $\quad$ Achim Brauer (brau@gfz-potsdam.de)

Relevant dates: $\quad$ Published: 15 August 2019

How to cite: Brauer, A., Schwab, M. J., Brademann, B., Pinkerneil, S., and Theuerkauf, M.: Tiefer See - a key site for lake sediment research in NE Germany, DEUQUA Spec. Pub., 2, 89-93, https://doi.org/10.5194/deuquasp-2-89-2019, 2019.

Abstract:

Tiefer See formed in a subglacial gully system at the end of the last glaciation in the northeast German lowlands. The lake has been selected as a focus site within the TERENO (Terrestrial Environmental Observatory) NE German observatory because it forms annual laminations (calcite varves) providing detailed information of past climate and environmental changes. Our research integrates palaeolimnology and limnology by combining high-resolution analyses of the sediment record with a comprehensive monitoring of the lake and its sedimentation processes since 2012. This allows evaluation of the observed effects of ongoing climate change in the context of the long-term history of the lake. The lacustrine sediment profile comprises the last 13000 years and is dated by a multiple dating approach. The sedimentation is dominated by biochemical calcite formation and algal blooms. Detrital material from the catchment forms only a minor component even during times of increased human impact. Repeated changes between well-varved, poorly varved and homogeneous sediment intervals indicate that sedimentation processes in the lake are particularly sensitive to changes in lake circulation. The research at Tiefer See is embedded in ICLEA (https://www.iclea.de, last access: 2 August 2019) and BaltRap (https://www.io-warnemuende.de/projekt/167/baltrap.html, last access: 2 August 2019) projects.

\section{Geomorphology and Geology}

Tiefer See is part of the Klocksin lake chain, a subglacial gully system in a morainic terrain located in the natural park Nossentiner/Schwinzer Heide at $53^{\circ} 35.5^{\prime} \mathrm{N}$, $12^{\circ} 31.8^{\prime} \mathrm{E}$. The Klocksin lake chain extends from NNE to SSW and includes the four lakes Flacher See (64.4 m a.s.l.), Tiefer See (62.9 m a.s.1.), Hofsee (62.7 m a.s.l.) and Bergsee (62.6 $\mathrm{m}$ a.s.1.). The catchment geology of the northern part of the lake chain including Tiefer See is formed by tills while the southern part consists of glacifluvial sands. Numerous er- ratics along the shoreline of Tiefer See indicate the proximity of terminal moraines which formed during the Pomeranian ice advance W2 at around $16 \mathrm{kyr}$ BP. Today, Tiefer See is connected to Hofsee in the south while the connection to Flacher See in the north has been channelised in a tunnel after construction of a railway dam between the two lakes. Tiefer See has a surface area of ca. $0.75 \mathrm{~km}^{2}$ and the catchment area is about $5.5 \mathrm{~km}^{2}$. With a maximum depth of 62 to $63 \mathrm{~m}$ Tiefer See is the deepest lake of the Klocksin lake chain (Fig. 1). It has no major inflow and outflow. The presentday lake water is mesotrophic and the circulation mode is 


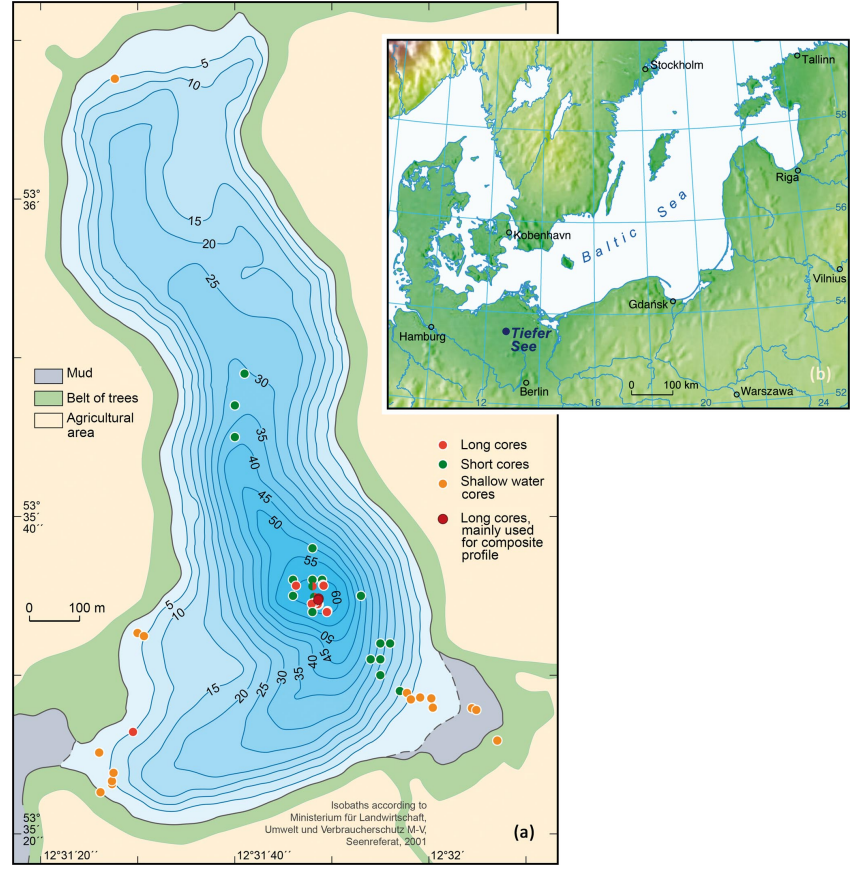

Figure 1. (a) Lake bathymetry and core locations (red: long cores; green: surface cores; orange: shallow water cores). (b) Tiefer See location.
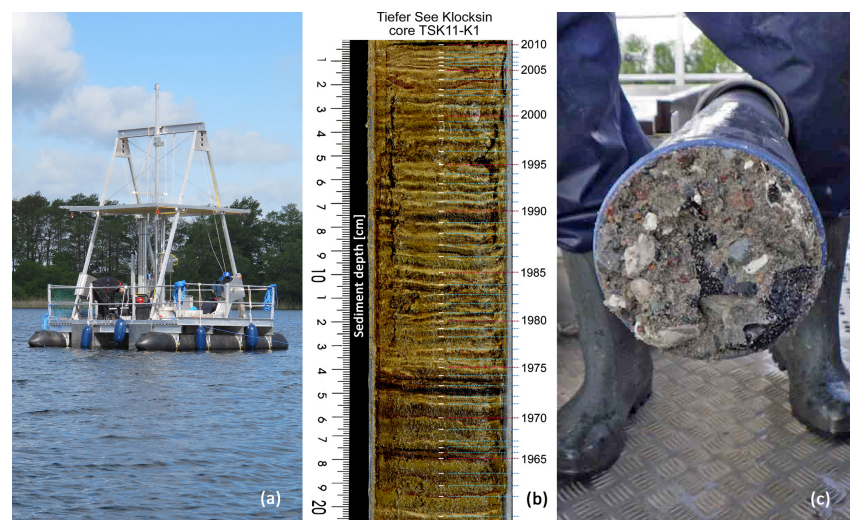

Figure 2. (a) GFZ lake sediment coring device (https://www. UWITEC.at, last access: 2 August 2019); (b) subrecent varves; (c) basal gravel and sand.

either mono- or dimictic, depending on the formation of a winter ice cover (Kienel et al., 2013). The climate is warmtemperate at the transition from oceanic to continental conditions. Mean monthly temperatures range from $0^{\circ} \mathrm{C}$ in January to $17-18^{\circ} \mathrm{C}$ in July with maxima up to $30^{\circ} \mathrm{C}$ and minima down to $-5^{\circ} \mathrm{C}$. Mean monthly precipitation varies between ca. $40 \mathrm{~mm}$ during winter and ca. $60 \mathrm{~mm}$ in summer with a mean annual precipitation of $560-570 \mathrm{~mm}$. Although the catchment is mainly used for agriculture, the direct shoreline of the lake is covered by a fringe of trees without any buildings and roads.

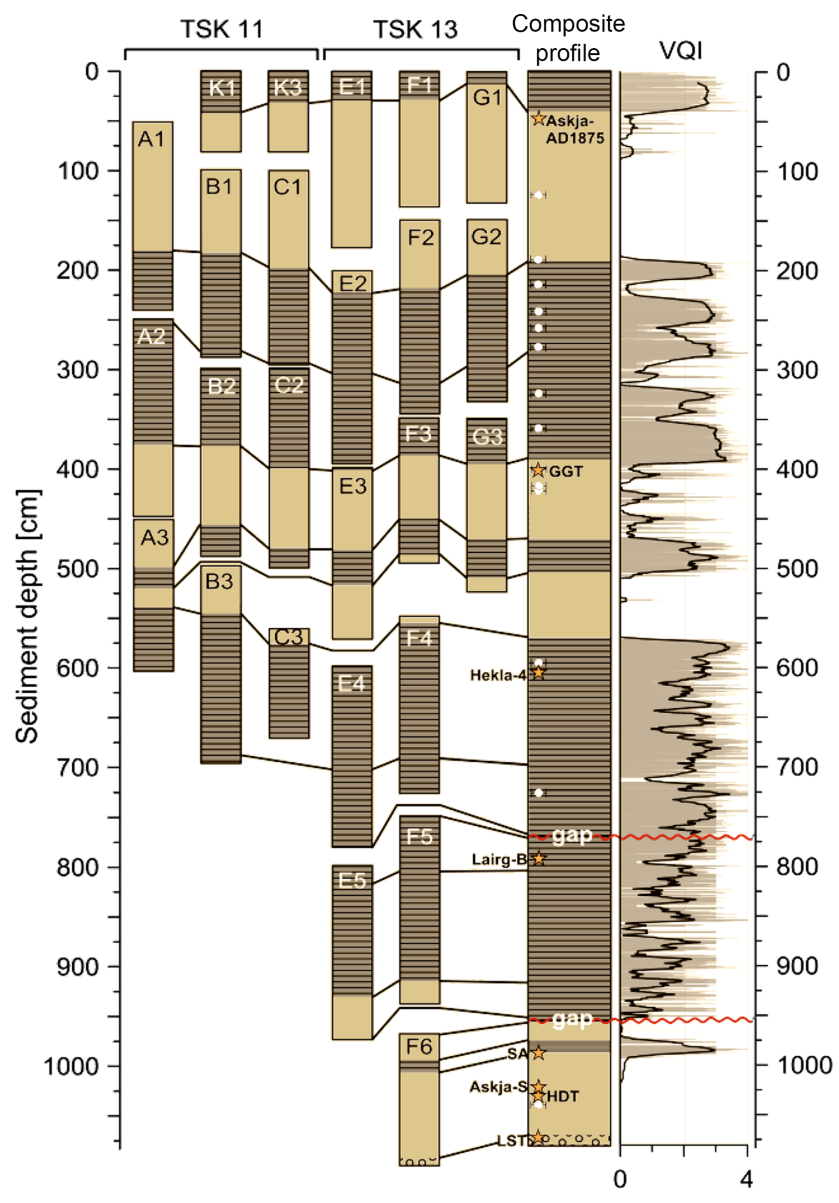

Figure 3. Schematic profiles of Tiefer See sediment cores and the respective composite profile with well-varved (dark) and nonvarved (light) sections; white dots indicate AMS 14C dates, and orange stars show positions of cryptotephras (data from Wulf et al., 2016).

\section{The sediment profile}

In addition to several surface sediment cores from the entirety of the lake basin, a total of nine overlapping sediment cores have been obtained from the deepest part of the lake (Fig. 1a) with the GFZ piston coring device (Fig. 2a) during three field campaigns in 2011, 2013 and 2019. A composite profile has been established from six cores which includes two minor gaps below $7.5 \mathrm{~m}$ depth in the early Holocene (Dräger et al., 2017). These gaps have been closed with the new cores taken in 2019. The composite profile is about $11 \mathrm{~m}$ long and depicts a main lithological change from basal sands and gravel (Fig. 2c) to massive fine-grained and calcite-rich lacustrine sediments at about $10.7 \mathrm{~m}$ depth. At $10.4 \mathrm{~m}$ sediment depth (Fig. 3) a rapid transition to organic-rich sediments occurred. The organic-rich sediments vary in structure from finely laminated to poorly laminated and massive. The finely laminated sediments represent three different microfacies types of varves, (1) Ca-rhodochrosite varves, (2) or- 

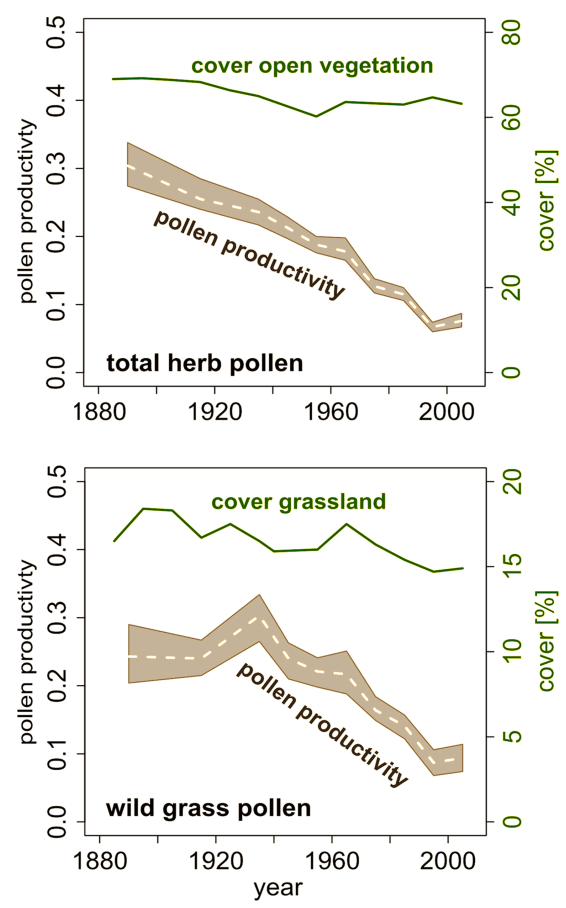

Figure 4. Changes in the cover of open vegetation and grasslands in the surroundings of Tiefer See, and changes in the mean pollen productivity of herbs and grasses since $1880 \mathrm{CE}$ (after Theuerkauf et al., 2015).

ganic varves and (3) calcite varves (Dräger et al., 2017). The most recent period of varve preservation began in $1924 \mathrm{CE}$ (Kienel et al., 2017) with the formation of calcite varves (Fig. 2b). The alternation of varved and poorly or non-varved sediment intervals is also reflected in stable carbon isotope data of organic matter which is interpreted as variations between predominantly anoxic and oxic lake bottom waters (Dräger et al., 2019). The frequency and duration of poorly varved intervals increased during the late Holocene and has been related to either climatic changes (increased windiness) or human impact in the catchment (Dräger et al., 2017).

\section{The age-depth model}

Dating is crucial for robust reconstruction of past climate and environment changes. Therefore, a multiple dating approach has been applied for the sediment record from Tiefer See including varve counting, radiocarbon dating, tephrochronology and ${ }^{10} \mathrm{Be}$ analyses. Due to the minor gaps in the lower part of the sediment profile, a robust and continuous chronology could be established only for the last $6030 \pm 85 \mathrm{yrs} B \mathrm{PP}$ (ca. $7.5 \mathrm{~m}$ sediment depth). Varves have been counted using a petrographic microscope and non-varved intervals have been interpolated using sedimentation rate estimates based on microstructural analyses on thin sections. The resulting varve chronology has been confirmed by 12 radiocarbon dates of organic macroremains and by three cryptotephra

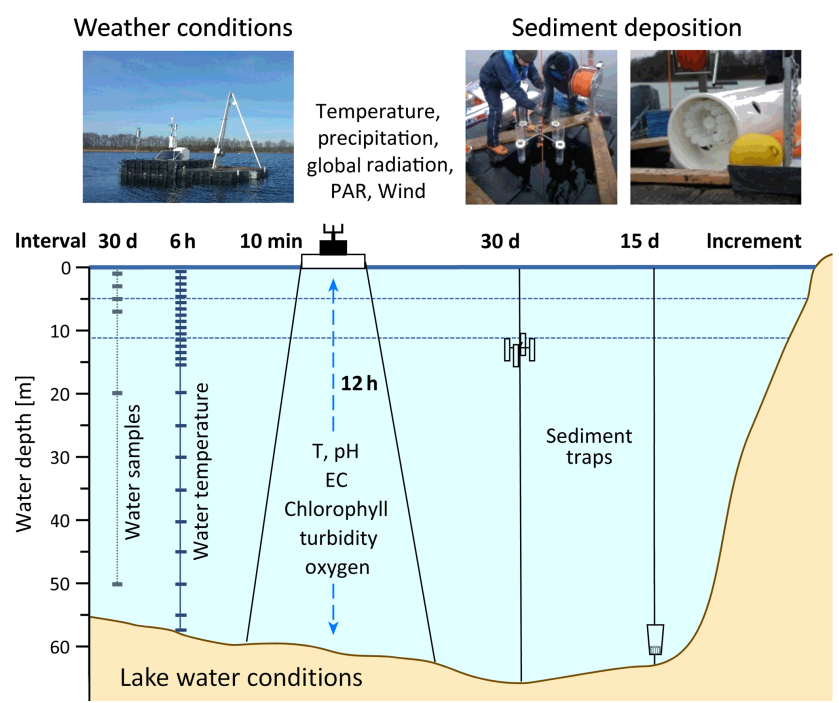

Figure 5. Sketch of installed lake sediment monitoring equipment in Tiefer See.

horizons: (1) the Askja $1875 \mathrm{CE}$, (2) the Glen Garry (2088 \pm 122 yrs BP) and (3) the Hekla 4 tephra ( $4293 \pm 43$ yrs BP). The identification of another five Holocene cryptotephras of Icelandic origin in the lower part of the sediment profile (Hässeldalen, Askja-S, Saksunarvatn, Lairg B; Wulf et al., 2016) provides a good estimate of the early Holocene age model. ${ }^{10} \mathrm{Be}$ data further confirmed the chronology and allowed an independent synchronisation with the varved sediment record from Lake Czechowskie a few hundred kilometres further east (Czymzik et al., 2015, 2018). The base of the profile is dated into the late Allerød through the detection of glass shards from the Laacher See eruption (12880 yrs BP).

\section{Pollen analyses}

The seasonal resolution of the sediments allows for tracing historical land-use changes in great detail (Theuerkauf et al., 2015). Varve dating enabled us to accurately estimate pollen deposition of herbs and trees over the past 150 years, which has then been compared to the contemporaneous land cover documented in archival data (Fig. 4; Theuerkauf et al., 2015). Interestingly, the strong decline in herb pollen deposition since the 1950s did not reflect a change in the cover of arable land and grassland. Instead, pollen deposition of herbs and grasses was controlled by changes in pollen productivity in response to intensified land management. Today, grassland is mown earlier and more frequently, giving the grasses less time to flower and produce pollen than previously. This study demonstrated that the modern vegetation is not always a reliable reference for the past. Therefore, the ROPES approach without pollen productivity as a parameter has been developed for the long pollen record of the last 6000 years from Tiefer See (Theuerkauf and Couwenberg, 2018). 
Pollen analyses in combination with sedimentological parameters as well as macrofossil and microfossil analysis from 20 sediment cores along the shore of Tiefer See and in adjacent peatlands were applied for Holocene lake level reconstruction. We found Holocene lake level fluctuations with an amplitude of about $10 \mathrm{~m}$, which exceeds by far recently observed variations. Based on radiocarbon age modelling, the lowest lake levels occurred during the early Holocene and maxima in the medieval period. These changes are only partly related to climatic changes but we also observe a link to changes in forest cover. In particular during medieval times, large-scale forest opening likely increased groundwater formation and thus contributed to lake level increases.

\section{Lake and sedimentation monitoring}

A comprehensive lake monitoring instrumentation (Fig. 5) has been installed on Tiefer See since 2012 in order to decipher the response of the lake to ongoing climate change (Heinrich et al., 2018) and to study in detail the processes that transform weather signal into the sediment record. The instrumentation includes a permanent weather station on the lake measuring temperature, relative humidity, solar radiation, rainfall and wind speed in $10 \mathrm{~min}$ intervals. Attached to the weather station is an automatic probe that measures water parameters from the epilimnion to the lake bottom every $12 \mathrm{~h}$. These measurements are complemented by temperature loggers permanently installed in $1 \mathrm{~m}$ apart down to $15 \mathrm{~m}$ water depth and $5 \mathrm{~m}$ apart down to $55 \mathrm{~m}$ depth. In addition, lake water is sampled monthly at water depths of 1, 3, 5, 7, 20 and $50 \mathrm{~m}$ for chemical analyses and stable oxygen and deuterium isotopes. Sediments are trapped in monthly intervals in two four-cylinder traps, one directly below the productive zone in the epilimnion and one in the hypolimnion. In the hypolimnion is a sequential trap with $15 \mathrm{~d}$ sample intervals installed. First results of the water isotope analyses revealed a seasonal $1.5 \%$ enrichment of $\delta^{18} \mathrm{O}$ proving the expected evaporative loss of surface water of up to $10 \%$ during the summer, which corresponds to the observed lake level drop of $50 \mathrm{~cm}$. Interestingly, the deep water also generally has more positive $\delta^{18} \mathrm{O}$ values than the annual rainwater mean collected on the weather station. The isotopic enrichment of the deep water indicates a long water residence time in the lake, which is likely due to the lack of major in- and outflows and low groundwater inflow. The intensive monitoring also allowed the investigation of the effects of the 2018 summer heatwave on the lake hydrology (Heinrich et al., 2019).

Data availability. No data sets were used in this article.

Author contributions. AB, MJS and MT wrote the text. SP, BB, MJS and MT participated in the fieldwork and took the photographs in Fig. 2. All authors contributed to the discussion and interpreta- tion of the presented research results. Additional information and supplementary data about this project are published (Czymzik et al., 2015, 2018; Dräger et al., 2017, 2019; Heinrich et al., 2018, 2019; Kienel et al., 2013, 2017; Theuerkauf et al., 2015, Theuerkauf and Couwenberg, 2018; Wulf et al., 2016).

Competing interests. The authors declare that they have no conflict of interest.

Acknowledgements. This study is a contribution to the Virtual Institute of Integrated Climate and Landscape Evolution Analysis - ICLEA - of the Helmholtz Association (VH-VI-415) and to BaltRap: The Baltic Sea and its southern Lowlands: proxy-environment interactions in times of Rapid change (SAW-2017-IOW2). We acknowledge support for the article processing charge from the DFG (no. 393148499) and the Open Access Publication Fund of the University of Greifswald.

Financial support. This research has been supported by the DFG (German Research Foundation, grant no. 393148499) and the Open Access Publication Fund of the University of Greifswald.

\section{References}

Czymzik, M., Muscheler, R., Brauer, A., Adolphi, F., Ott, F., Kienel, U., Dräger, N., Słowiński, M., Aldahan, A., and Possnert, G.: Solar cycles and depositional processes in annual ${ }^{10} \mathrm{Be}$ from two varved lake sediment records, Earth Planet. Sc. Lett., 428, 44-51, 2015.

Czymzik, M., Muscheler, R., Adolphi, F., Mekhaldi, F., Dräger, N., Ott, F., Słowinski, M., Błaszkiewicz, M., Aldahan, A., Possnert, G., and Brauer, A.: Synchronizing 10Be in two varved lake sediment records to IntCal13 14C during three grand solar minima, Clim. Past, 14, 687-696, https://doi.org/10.5194/cp-14-6872018, 2018.

Dräger, N., Theuerkauf, M., Szeroczynska, K., Wulf, S., Tjallingii, R., Plessen, B., Kienel, U., and Brauer, A.: A varve micro-facies and varve preservation record of climate change and human impact for the last 6000 years at Lake Tiefer See (NE Germany), Holocene 27, 450-464, https://doi.org/10.1177/0959683616660173, 2017.

Dräger, N., Plessen, B., Kienel, U., Słowiński, M., Ramisch, A., Tjallingii, R., Pinkerneil, S., and Brauer, A.: Relation Hypolimnetic oxygen conditions influence varve preservation and $\delta^{13} \mathrm{C}$ of sediment organic matter in Lake Tiefer See, NE Germany, J. Paleolimnol., 62, 181-194, https://doi.org/10.1007/s10933-01900084-2, 2019.

Heinrich, I., Balanzategui, D., Bens, O., Blume, T., Brauer, A., Dietze, E., Gottschalk, P., Güntner, A., Harfenmeister, K., Helle, G., Hohmann, C., Itzerott, S., Kaiser, K., Liebner, S., Merz, B., Pinkerneil, S., Plessen, B., Sachs, T., Schwab, M. J., Spengler, D., Vallentin, C., and Wille, C.: Regionale Auswirkungen des Globalen Wandels: Der Extremsommer 2018 in Nordostdeutschland, System Erde, 9, 38-47, https://doi.org/10.2312/GFZ.syserde.09.01.6, 2019. 
Heinrich, I., Balanzategui, D., Bens, O., Blasch, G., Blume, T., Böttcher, F., Borg, E., Brademann, B., Brauer, A., Conrad, C., Dietze, E., Dräger, N., Fiener, P., Gerke, H. H., Güntner, A.,Heine, I., Helle, G., Herbrich, M., Harfenmeister, K., Heußner, K., Hohmann, C., Itzerott, S., Jurasinski, G., Kaiser, K., Kappler, C., Koebsch, F., Liebner, S., Lischeid, G., Merz, B., Missling, K. D., Morgner, M., Pinkerneil, S., Plessen, B., Raab, T., Ruhtz, T., Sachs, T., Sommer, M., Spengler, D., Stender, V., Stüve, P., and Wilken, F.: Interdisciplinary Geoecological Research across Time Scales in the Northeast German Lowland Observatory (TERENO-NE), Vadose Zone J., 17, 25, https://doi.org/10.2136/vzj2018.06.0116, 2018.

Kienel, U., Dulski, P., Ott, F., Lorenz, S., and Brauer, A.: Recently induced anoxia leading to the preservation of seasonal laminae in two NE-German lakes, J. Paleolimnol., 50/4, 535-544, 2013.

Kienel, U., Kirillin, G., Brademann, B., Plessen, B., Lampe, R., and Brauer, A.: Effects of spring warming and mixing duration on diatom deposition in the deep Tiefer See, NE Germany, J. Paleolimnol., 57, 37-49, 2017.
Theuerkauf, M. and Couwenberg, J.: ROPES Reveals Past Land Cover and PPEs From Single Pollen Records, Front. Earth Sci., 6, https://doi.org/10.3389/feart.2018.00014, 2018.

Theuerkauf, M., Dräger, N., Kienel, U., Kuparinen, A., and Brauer, A.: Effects of changes in land management practices on pollen productivity of open vegetation during the last century derived from varved lake sediments, Holocene, 25, 733-744, 2015.

Wulf, S., Dräger, N., Ott, F., Serb, J., Appelt, O., Gudmundsdottir, E., van den Bogaard, C., Słowinski, M., Błaszkiewicz, M., and Brauer, A.: Holocene tephrostratigraphy of varved sediment records from Lakes Tiefer See (NE Germany) and Czechowskie (N Poland), Quaternary Sci. Rev., 132, 1-14, 2016. 